\title{
Peran Kepala Sekolah Dalam Meningkatkan Mutu Pendidiikan Agama Islam Di Madarasah Aliyah Muhammadiyah 02 Paciran Lamongan
}

\author{
Subhan Adi Santoso \\ Program Studi Pendidikan Agama Islam \\ Sekolah Tinggi Ilmu Tarbiyah Muhammadiyah Paciran, Indonesia \\ Email: subhan.stitm@gmail.com
}

\begin{abstract}
The objectives to be achieved in this study are 1) to determine the role of school principals in improving the quality of Islamic religious education. 2) to find out the efforts of school principals in improving the quality of Islamic religious education. 3) to determine the supporting and inhibiting factors in improving the quality of Islamic religious education at Madarasah Aliyah Muhammadiyah 02 Paciran Lamongan.

From the results of the study, it was concluded that the principal tried to improve the quality and knowledge of teachers by holding discussions, trainings, seminars and so on. The principal pays attention to the development of student activities in teaching and learning activities, in this case the principal sees directly what is used by teachers, student activity reports, and student attendance books. The principal also tries to equip school infrastructure and equipment including instructional media needed for the smooth and successful teaching and learning process. Completing library books because it is important for the development of the quality of education. Supporting factors in improving the quality of Islamic religious education are the role of effective school principals, exemplary teachers, outstanding students and human resources.
\end{abstract}

Keywords: Principal, Quality of Islamic Religious Education

\section{Pendahuluan}

Pendidikan mempunyai peran yang sangat besar dan sekaligus merupakan sumber daya yang sangat penting. Khususnya bagi negara yang sedang berkembang. Dari uraian di atas maka sebagai salah satu jalan keluar yang paling baik untuk mengatasi hal tersebut adalah melalui jalan pendidikan karena pendidikan merupakan suatu kebutuhan yang sangat penting bagi kehidupan manusia. Dengan pendidikan akan membantu membentuk kepribadian dimasa yang akan datang dan sekaligus juga mempunyai fungsi untuk mengembangkan kemampuan serta meningkatkan mutu kehidupan dan martabat manusia Indonesia dalam rangka mewujudkan tujuan nasional.

Hal ini sebagaimana dikemukakan dalam pembukaan Undang-Undang Republik Indonesia No. 20 Tahun 2003 Tentang Sistem Pendidikan Nasional, Bab II pasal 2 dan 3, yang berbunyi sebagai berikut:

1. Pasal 2: Pendidikan Nasional berdasarkan Pancasila dan Undang-Undang Dasar Negara Republik Indonesia Tahun 1945.

2. Pasal 3: Pendidikan Nasional berfungsi mengembangkan kemampuan dan membentuk watak serta peradaban bangsa yang bermartabat dalam rangka mencerdaskan kehidupan bangsa, bertujuan untuk berkembangnya potensi peserta didik agar menjadi 
manusia yang beriman dan bertakwa kepada Tuhan Yang Maha Esa, berakhlak mulia, sehat, berilmu, cakap, kreatif, mandiri dan menjadi warga negara yang demokratis dan serta bertanggung jawab (Undang-Undang Tentang Sistem Pendidikan Nasional, 2003, p.8).

Sarana yang paling strategis untuk mewujudkan peningkatan sumber daya manusia adalah melalui pendidikan. Akan tetapi, bidang pendidikan yang strategis ini akan bermakna dan dapat mencapai tujuannya apabila pendidikan tersebut memiliki sistem yang relevan dengan pembangunan dan kualitas yang tinggi baik dari segi proses maupun hasilnya.

Mengelola dan mengembangkan sekolah menjadi maju dan bermutu terletak pada mutu warga sekolah, misalnya kepala sekolah, guru, staf administrasi, siswa, masyarakat serta iklim dan kultur di sekitarnya. Untuk mengelola sekolah, diperlukan kepala sekolah yang dapat mengatur seluruh potensi sekolah agar berfungsi dengan baik untuk mendukung tercapainya tujuan sekolah. Disamping itu, sekolah harus memiliki visi, misi dan manajemen yang baik untuk diaktualisasikan dalam tugas atau perannya sebagai edukator, manajer, administrator, supervisor, leader, inovator dan motivator.

Sebagaimana yang telah diketahui bahwa kepala sekolah di samping memiliki kedudukan di sekolah juga di masyarakat. Dalam kaitannya dengan peran di masyarakat, kepala sekolah juga harus mengenal badan dan lembaga masyarakat yang dapat menunjang pendidikan dan mengenal perubahan sosial ekonomi dan politik masyarakat.

Sebagai pemimpin pendidikan, kepala sekolah bertanggung jawab untuk pertumbuhan guru secara continue. Dengan praktek demokratis ia harus mampu membantu guru untuk mengenal kebutuhan masyarakat sehingga tujuan pendidikan bisa memenuhi syarat tersebut dan ia harus mampu membantu guru untuk mengevaluasi program pendidikan dan hasil belajar murid. Kepemimpinan kepala sekolah merupakan salah satu faktor yang dapat mendorong sekolah untuk dapat mewujudkan misi, visi dan sasaran sekolah melalui program-program yang dilaksanakan secara terencana dan bertahap (Mulyasa, 2004, p.182). Oleh karena itu, kepala sekolah dituntut memiliki kemampuan manajemen dan kepemimpinan yang bagus agar mampu mengambil keputusan dan prakarsa untuk meningkatkan mutu pendidikan di sekolah.

Kepemimpinan merupakan kemampuan seseorang dalam mempengaruhi orang lain, baik individu, kelompok serta kemampuan untuk mengarahkan tingkah laku individua atau kelompok untuk memiliki kemampuan atau keahlian khusus dalam bidang yang diinginkan oleh kelompoknya. Sehingga bawahan dengan senang hati mau melaksanakan tugas yang diberikan untuk mencapai tujuan yang telah ditentukan (Subhan Adi Santoso, 2018, p.44-45). 
Salah satu unsur untuk meningkatkan mutu pendidikan dan untuk mewujudkan tujuan pendidikan nasional lebih-lebih di tingkat sekolah maka pertama tidak lepas dari usaha, yaitu dengan cara membenahi sistem pengelolahan sekolah, administrasi sekolah, kedisiplinan, peningkatan kemampuan guru dalam mengajar, kerjasama antara sekolah dan masyarakat.

Tetapi kenyataan yang terjadi tidak semua kepala sekolah memainkan perannya dengan baik dan benar, tidak sedikit pula kepala sekolah yang kurang optimal atau setengah hati dalam mengelola sebuah lembaga sekolah terutama dalam penanamkan moralitas yang ada di dalam pendidikan agama Islam terhadap peserta didik.

Saat ini bangsa Indonesia masih sedang mengalami suasana keprihatinan yang bertui-tubi. Predikat sebagai negeri terkorup masih disandang oleh negara kita, KKN melanda di berbagai institusi, disiplin makin longgar dan semakin meningkatnya tindak kriminal, tindak kekerasan, anarchisme, premanisme, konsumsi minuman keras dan narkoba sudah melanda dikalangan pelajar dan mahasiswa serta masih maraknya perkelahian antar pelajar. Masyarakat kita juga cenderung mengarah pada masyarakat kepentingan, nilai-nilai masyarakat paguyuban sudah ditinggalkan, yang tampak dipermukaan adalah timbulnya konflik kepentingan-kepentingan, baik kepentingan individu, kelompok, agama, etnis, politik maupun kepentingan lainnya.

Dari hasil kajian dari berbagai disiplin dan pendekatan, tampaknya ada kesamaan pandangan bahwa segala macam krisis itu berpangkal dari krisis akhlak atau moral. Krisis ini, secara langsung atau tidak sangat berhubungan dengan persoalan pendidikan. Kontribusi pendidikan dalam kontek ini adalah pada pembangunan mentalitas manusia yang merupakan produknya. Ironisnya, krisis tersebut menurut sementara pihak disebabkan karena kegagalan pendidikan agama termasuk di dalamnya pendidikan agama Islam.

Harus diakui bahwa pendidikan agama Islam masih belum mendapat tempat dan waktu yang proporsional, terutama di sekolah umum. Lebih dari itu, karena tidak termasuk kelompok mata pelajaran yang di UAN-kan, keberadaannya sering kali kurang mendapat perhatian.

Berdasarkan pada fenomena, maka dalam penulisan, penulis tertarik untuk mengambil judul "Peran Kepala Sekolah Dalam Meningkatkan Mutu Pendidiikan Agama Islam Di Madarasah Aliyah Muhammadiyah 02 Paciran Lamongan”

Berdasarkan uraian latar belakang yang telah dikemukakan di atas, maka penulis dapat merumuskan permasalahan pokok sebagai berikut: 
1. Bagaimana peran kepala sekolah dalam meningkatkan mutu Pendidikan Agama Islam di Madarasah Aliyah Muhammadiyah 02 Paciran Lamongan?

2. Bagaimana usaha yang dilakukan kepala sekolah dalam meningkatkan mutu pendidikan agama Islam di Madarasah Aliyah Muhammadiyah 02 Paciran Lamongan?

3. Faktor apa yang mendukung dan menghambat dalam meningkatkan mutu pendidikan agama Islam di Madarasah Aliyah Muhammadiyah 02 Paciran Lamongan?

\section{Landasan Teori}

\section{Tugas dan Fungsi Kepala Sekolah}

Sekolah adalah lembaga yang bersifat kompleks dan unik. Bersifat kompleks karena sekolah sebagai organisasi yang di dalamnya terdapat berbagai dimensi yang satu sama yang lain saling berkaitan dan saling menentukan. Sedangkan sifat uniknya adalah menunjukan bahwa sekolah sebagai organisasi memiliki ciri-ciri tertentu yang tidak dimiliki oleh organisasi-organisasi lain. Ciri-ciri yang menempatkan sekolah memiliki karakter tersendiri, di mana terjadi proses belajar mengajar, tempat terselenggaranya pembudayaan kehidupan manusia. Sesuai dengan ciri-ciri sekolah sebagai organisasi yang bersifat komplek dan unik, tugas dan fungsi kepala sekolah seharusnya dilihat dari berbagai sudut pandang. Di samping menjalankan tugas manajerial, kepala sekolah berperan penting untuk menjalankan kepemimpinan guna memajukan pengajaran (Hendiyat Sutopo dan Wasty Suemanto, 1982, p.62).

Menurut Wijono, tugas seorang kepala sekolah secara garis besar dapat dikelompokan menjadi tiga, yaitu administrasi material, administrasi personel dan administrasi kurikulum (Wijono, 1989, p.18). Administrasi material adalah administrasi yang menyacup bidang-bidang material sekolah seperti ketatausahaan sekolah, keuangan, pergedungan, perlengkapan, dan lain-lain. Administrasi personel adalah administrasi yang mencakup administrasi keguruan, kemuridan, dan pegawai sekolah lainnya. Administrasi kurikulum adalah administrasi yang mencakup penyusunan kurikulum, pembinaan kurikulum dan pelaksanaan kurikulum. Kepemimpinan dan administratif pendidikan yang berhasil bagi kepala sekolah adalah diarahkan pada pengembangan aktifitas pengajaran dan belajar siswa.

Peran kepala sekolah sebagai administrator pendidikan bertanggung jawab terhadap kelancaran pelaksanaan pendidikan dan pengajaran di sekolahnya. Oleh karena itu, untuk dapat melaksanakan tugasnya dengan baik, kepala sekolah hendaknya memahami, menguasai 
dan mampu melaksanakan kegiatan-kegiatan yang berkenaan dengan fungsinya sebagai administrator pendidikan.

Adapun peran kepala sekolah sebagai administrator pendidikan adalah membuat perencanaan atau program tahunan, menyusun organisasi sekolah, bertindak sebagai koordinator dan pengarah dan melaksanakan pengelolaan kepegawaian (Ngalim Purwanto, 1990, p.106).

Sedangkan peran kepala sekolah sebagai supervisor adalah bagaimana kepala sekolah melakukan kegiatan pembinaan yang direncanakan untuk membantu para guru dan pegawai sekolah dalam melakukan pekerjaan mereka secara efektif.

Fungsi supervisi dalam dunia pendidikan bukan hanya sekedar kontrol melihat apakah segala kegiatan telah dilaksanakan sesuai dengan rencana atau program yang telah digariskan tetapi juga menentukan kondisi-kondisi atau syarat-syarat personil maupun material yang diperlukan untuk terciptanya situasi belajar mengajar yang efektif serta berusaha bersama guru-guru dan karyawan sekolah untuk mencari perbaikan ke arah yang lebih bermutu dalam proses belajar mengajar.

Adapun fungsi kepala sekolah sebagai supervisor antara lain membangkitkan dan merangsang guru-guru dan pegawai sekolah di dalam menjalankan tugasnya dengan sebaikbaiknya, bersama guru-guru berusaha mengembangkan dan menggunakan metode-metode mengajar yang lebih sesuai dengan tuntutan kurikulum yang berlaku dan membina kerjasama yang baik serta harmonis di antara warga sekolah.

Kepala sekolah juga berperan sebagai manajer. Manajer dalam arti umum adalah proses untuk menyelenggarakan dan mengawasi kegiatan-kegiatan untuk mencapai suatu tujuan tertentu dengan menggunakan orang-orang pelaksana (Ngalim Purwanto, 1990, p.115).

1. Kepala Sekolah dalam Menjalankan Administrasi Pendidikan

Untuk dapat memahami administrasi pendidikan secara keseluruhan maka perlu membahas dahulu titik awal pengertian Administrasi dan Pendidikan. Menurut Sondang P. Siagian (dalam Daryanto) pengertian Administrasi adalah keseluruhan proses kerjasama antara dua orang atau lebih yang didasarkan atas rasionalitas tertentu, untuk mencapai tujuan yang telah ditentukan sebelumnya. Administrasi juga dapat diartikan sebgai aktivitas-aktivitas untuk mencapai suatu tujuan atau proses penyelenggaraan kerja untuk mencapai tujuan yang telah ditetapkan (M. Daryanto, 2001, p.7). 
Sedangkan pengertian Pendidikan menurut Zahara Idris adalah suatu proses yang berisi berbagai macam kegiatan yang sesuai dengan kegiatan seseorang untuk kehidupan sosialnya dan membantunya meneruskan kebiasaan-kebiasaan dan kebudayaan serta kelembagaan sosial dari generasi ke generasi (Zahara Idris dan Lisma Jamal, 1992, p.2). Dalam hal ini peran kepala sekolah sebagai manajer adalah mengelola orang-orangnya sebagai pelaksana proses belajar mengajar dalam meningkatkan mutu pendidikan.

Mengacu pada definisi di atas, terdapat beberapa hal yang berkenaan dengan pengertian administrasi pendidikan. Ada beberapa pengertian administrasi pendidikan menurut beberpa ahli sebagai berikut:

a. Hadari Nawawi mengatakan administrasi pendidikan adalah rangkaian kegiatan atau keseluruhan proses pengendalian usaha kerjasama sejumlah orang untuk mencapai tujuan pendidikan secara berencana dan sistimatis yang diselenggarakan dalam lingkungan tertentu, terutama berupa lembaga pendidikan formal (Hadari Nawawi, 1985, p.11).

b. H.M. Daryanto menjelaskan bahwa administrasi pendidikan adalah suatu cara bekerja dengan orang-orang dalam rangka usaha mencapai tujuan predikat yang efektif, yang berarti mendatangkan hasil yang baik dan tepat, sesuai dengan tujuan pendidikan yang telah ditentukan.

Melihat definisi di atas, jelas kiranya bahwa administrasi pendidikan meliputi berbagai aspek dan kegiatan yang kesemuanya ditujukan untuk mencapai tujuan Pendidikan (M. Daryanto, 2001, p.7).

2. Kepala Sekolah dalam Menjalankan Kepemimpinan

Dalam suatu organisasi peran kepemimpinan sangat dominan bagi maju mundurnya suatu kegiatan, karena seorang pemimpin merupakan motor penggerak atau motivator bagi orang-orang yang dipimpin.

Menurut Hendiyat Soetopo kepemimpinan adalah Suatu kegiatan dalam membimbing suatu kelompok sedemikian rupa sehingga tercapai tujuan dari kelompok itu yaitu tujuan bersama. Pengertian pendidikan itu bersifat universal, berlaku dan terdapat pada kepemimpinan berbagai bidang kegiatan atau hidup manusia (Hendiyat Soetopo dan Wasty Suemanto, 1984, p.1).

Menurut Dirawat dkk. Pengertian umum kepemimpinan adalah kemampuan dan kesiapan yang dimiliki seseorang untuk dapat mempengaruhi, mendorong, mengajak, menuntun, menggerakkan dan kalau perlu memaksa orang lain agar ia menerima 
pengaruh itu selanjutnya berbuat sesuatu yang dapat membantu pencapaian suatu maksud atau tujuan tertentu (Dirawat dkk., 1983, p.23).

Bagi sejumlah ahli, kepemimpinan ialah proses mempengaruhi kegiatan seseorang atau sekelompok dalam usaha-usaha ke arah pencapaian tujuan dalam situasi tertentu. Dari pengertian di atas dapat diketahui bahwa dalam kepemimpinan terdapat:

a. Kepemimpinan yaitu orang yang dapat mempengaruhi orang lain.

b. Orang yang dipimpin yaitu orang yang menerima pengaruh.

c. Tujuan yang hendak dicapai seorang pemimpin adalah pribadi yang memiliki kecakapan khusus, tanpa pengangkatan resmi yang dapat mempengaruhi kelompok yang dipimpinnya, untuk melakukan usaha bersama mengarah pada pencapaian sasaran-sasaran tertentu.

Jadi, kepemimpinan dalam organisasi pendidikan barangkali dapat dirumuskan sebagai kemampuan seseorang untuk mengambil inisiatif dalam kegiatan sosial untuk merangsang dan mengorganisasi tindakan-tindakan dan membangkitkan kerjasama yang efektif kearah pencapaian tujuan-tujuan pendidikan.

\section{Pendidikan Agama Islam}

1. Pengertian Pendidikan Agama Islam

Untuk memahami pengertian pendidikan Islam ini secara mendalam, maka penulis akan mengemukakan beberapa pendapat tentang pendidikan agama Islam sebagai berikut: Menurut Zakiah Daradjat pendidikan agama Islam atau At-Tarbiyah AlIslamiah adalah usaha bimbingan dan asuhan terhadap anak didik agar kelak setelah selesai pendidikannya dapat memahami dan mengamalkan ajaran agama Islam serta menjadikannya sebagai pandangan hidup (Zakiah Daradjat, 1996, p.86).

Sedangkan menurut Ahmad D. Marimba (dalam Umi Uhbiyat) pendidikan Islam adalah: bimbingan jasmani dan rohani berdasarkan hukum-hukum agama Islam, menuju terciptanya kepribadian utama menurut ukuran Islam (Nur Uhbiyati, 1998, p.9).

Pendidikan agama Islam adalah suatu kegiatan yang bertujuan menghasilkan orangorang beragama, dengan demikian pendidikan agama perlu diarahkan ke arah pertumbuhan moral dan karakter (Zuhairini dan Abdul Ghofir, 2004, p.1).

Ditinjau dari beberapa definisi pendidikan agama Islam di atas dapat disimpulkan bahwa pendidikan agama Islam adalah sebagai berikut:

a. Segala usaha berupa bimbingan terhadap perkembangan jasmani dan rohani anak, menuju terbinanya kepribadian utama sesuai dengan ajaran agama Islam. 
b. Suatu usaha untuk mengarahkan dan mengubah tingkah laku individu untuk mencapai pertumbuhan kepribadian yang sesuai dengan ajaran Islam dalam proses kependidikan melalui latihan-latihan akal pikiran (kecerdasan, kejiwaan, keyakinan, kemauan dan perasaan serta panca indra) dalam seluruh aspek kehidupan manusia.

c. Bimbingan secara sadar dan terus menerus yang sesuai dengan kemampuan dasar (fitrah dan kemampuan ajarannya pengaruh diluar) baik secara individu maupun kelompok sehingga manusia memahami, menghayati, dan mengamalkan ajaran agama Islam secara utuh dan benar. Yang dimaksud utuh dan benar adalah meliputi Aqidah (keimanan), Syari'ah (ibadah muamalah) dan akhlaq (budi pekerti).

\section{Tujuan Pendidikan Agama Islam}

Pendidikan secara sederhana diartikan sebagai proses menuju tujuan pendidikan yang hendak dicapai. Tanpa adanya tujuan yang jelas akan menimbulkan kekaburan atau ketidakpastian, maka tujuan pendidikan merupakan faktor yang teramat penting dalam proses pendidikan.

Untuk memberikan gambaran yang jelas tentang tujuan pendidikan agama Islam, maka berikut ini akan penulis kemukakan pendapat beberapa ahli mengenai tujuan pendidikan agama Islam:

a. Menurut Ahmad D. Marimba (dalam Umi Uhbiyat) tujuan pendidikan Islam adalah mencakup tujuan sementara dan tujuan akhir pendidikan Islam. Untuk mencapai tujuan akhir pendidikan harus dilampaui terlebih dahulu beberapa tujuan sementara. Tujuan akhir pendidikan Islam adalah terbentuknya kepribadian muslim (Nur Uhbiyati, 1998, p.30).

b. Menurut M. Athiyah Al-Abrasy, bahwa tujuan pendidikan agama Islam adalah "pembentukan akhlakul karimah" (M.Athiyah Al-Abrasyi, 1970, p.10).

c. Zakiah Daradjat, bahwa tujuan pendidikan agama adalah meliputi seluruh aspek kemanusiaan yang meliputi sikap, tingkah laku, penampilan, kebiasaan dan pandangan (Zakiah Daradjat, 1996, p.30).

Dari beberapa pendapat tersebut di atas dapat diambil kesimpulan bahwa tujuan pendidikan agama Islam adalah memahami ajaran-ajaran Islam secara sederhana dan bersifat menyeluruh, sehingga dapat digunakan sebagai pedoman hidup dan amalan perbuatannya, baik dalam hubungannya dengan Allah, dengan masyarakat dan 
hubungan dengan sekitarnya serta dapat membentuk pribadi yang berakhlak mulia sesuai dengan ajaran Islam.

\section{Mutu Pendidikan Agama Islam}

1. Pengertian Mutu Pendidikan

Orang sering mengatakan tentang mutu pendidikan, tetapi kurang jelasnya pengertian dari pada mutu pendidikan itu sendiri. Sehingga umumnya banyak orang yang mengatakan atau mengidentifikasikan mutu pendidikan dengan banyaknya lulusan dari pendidikan itu, atau kadang-kadang menonjolkan seseorang atau beberapa orang lulusanya.

Dari keracuhan tentang mutu pendidikan tersebut, dan untuk lebih mempermudah dalam kajian masalah ini perlu penulis kemukakan tentang pengertian dari mutu pendidikan.

Pius A. Partanto dan M. Dahlan dalam kamus Ilmiah Populer menjelaskan Mutu merupakan baik buruknya sesuatu, kualitas, taraf atau derajat (kepandaian, kecerdasan). Pendidikan perbuatan mendidik (Pius A. Partanto dan M. Dahlan, 1994, p.505). Jadi yang dimaksud dengan mutu pendidikan adalah kualitas seorang guru baik pemahamanya atau kemampuannya terhadap interaksi belajar mengajar yang indikatornya dapat dilihat dari hasil prestasi belajar siswa, baik itu prestasi dalam menempuh ujian semester ataupun prestasi dalam menempuh ujian akhir.

Pengertian mutu mengandung makna derajat (tingkat) keunggulan suatu produk baik berupa barang maupun jasa, baik yang dapat dipegang (tangible) maupun yang tidak dapat dipegang (intangible). Dalam konteks pendidikan, pengertian mutu dalam hal ini mengacu pada proses pendidikan dan hasil pendidikan. Dalam proses pendidikan yang bermutu terlibat berbagai input, seperti bahan ajar (kognitif, efektif dan psikomotorik), metodologi (bervariasi sesuai kemampuan guru), sarana sekolah, dukungan administrasi dan sumber daya lainnya serta penciptaan suasana belajar yang kondusif. Sedangkan mutu dalam konteks hasil pendidikan mengacu pada prestasi yang dicapai oleh sekolah pada setiap kurun waktu tertentu. Prestasi yang dicapai atau hasil pendidikan dapat berupa hasil tes kemampuan akademis dan dapat pula prestasi di bidang lain seperti prestasi di suatu cabang oleh raga, seni dan sebagainya.

Antara proses dan hasil pendidikan yang bermutu saling berhubungan. Akan tetapi agar proses yang baik itu tidak salah arah, maka mutu dalam artian hasil (output) harus dirumuskan dan harus jelas target yang akan dicapai dalam tiap tahun ataupun dalam kurun waktu tertentu. 
Adapun kriteria mutu pendidikan yang baik sekolahan diharapkan memiliki beberapa indikator yang menunjukkan bahwa sekolahan tersebut sudah bisa dibilang bermutu. Indikatornya adalah lingkungan sekolah yang aman dan tertib, sekolah memiliki tujuan dan target mutu yang ingin dicapai, sekolah memiliki kepemimpinan yang kuat, adanya pengembangan staff sekolah yang terus menerus sesuai dengan tuntutan iptek dan adanya pelaksanaan evaluasi yang terus menerus terhadap berbagai aspek akademik dan administratif serta pemanfaatan hasilnya untuk penyempurnaan atau perbaikan mutu Pendidikan (Mulyasa, 2005, p.85).

Begitu pula arti mutu dalam pendidikan agama Islam, hanya saja ada sedikit tambahan yaitu bagaimana sekolah atau madrasah bisa menyeimbangkan antara proses dan hasil pendidikan yang pada akhirnya peserta didik (lulusannya) menjadi manusia muslim yang berkualitas. Dalam arti, peserta didik mampu mengembangkan pandangan hidup, sikap hidup dan ketrampilan hidup yang berperspektif Islam. Pemahaman manusia berkualitas dalam khasanah pemikiran Islam sering disebut sebagai insan kamil yang mempunyai sifat-sifat antara lain manusia yang selaras (jasmani dan rohani, duniawi dan ukhrawi), manusia moralis (sebagai individu dan sosial), manusia nazhar dan i'tibar (kritis, berijtihad, dinamis, bersikap ilmiah dan berwawasan ke depan), serta menjadi manusia yang memakmurkan bumi (Muhaimin, 2005, p.201).

Dalam kaitannya dengan peningkatan mutu pendidikan maka tidak akan terlepas dari adanya beberapa faktor. Adapun faktor-faktor yang mempengaruhi akan dijelaskan berikut ini:

Beberapa faktor yang mempengaruhi peningkatan mutu pendidikan adalah sebagai berikut:
a. Kejelasan tujuan pendidikan di sekolah
b. Pengetahuan tentang anak didik
c. Pengetahuan tentang guru
d. Pengetahuan tentang kegiatan supervisi
e. Pengetahuan tentang mengajar
f. Kemampuan memperhitungkan waktu (Moh. Rifai, 1982, p.85).

2. Upaya Kepala Sekolah dalam Meningkatkan Mutu Pendidikan

Kepala sekolah sebagai seorang yang telah diberi wewenag untuk memimpin suatu lembaga pendidikan dan harus bertangungjawab secara penuh terhadap 
penyelenggaraan pendidikan pada sekolah yang berada dibawah pimpinanya. Sebagaimana sabda Rasulullah SAW yang berbunyi:

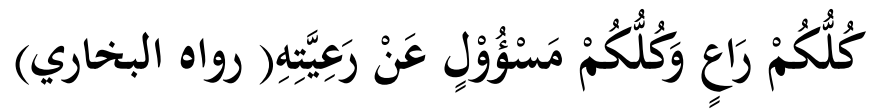

Artinya:"Semua kamu adalah pemimpin dan setiap kamu bertanggungjawab atas yang dipimpinnya"(HR. Bukhori) (Fachruddin HS, 1996, p.340)

Maju mundurnya suatu lembaga pendidikan itu banyak dipengaruhi oleh kepala sekolah, termasuk juga masalah peningkatan mutu pendidikan.

Adapun dalam peningkatan mutu pendidikan, kepala sekolah dapat melaksanakannya dengan melalui beberapa komponen antara lain:

a. Guru

Guru merupakan salah satu komponen yang memegang peranan yang sangat penting di dalam pelaksanaan pendidikan, karena itu kualitas seorang guru tersebut harus ditingkatkan.

Usaha peningkatan kualitas guru ini dapat dilaksanakan dengan berbagai cara, di antaranya adalah:

1) Meningkatkan kedisiplinan guru

Untuk meningkatkan mutu pendidikan faktor kedisiplinan guru sangat diperlukan, karena program sekolah akan dapat berjalan dengan baik jika guru-guru disiplin. Demikian sebaliknya jika guru-gurunya malas, maka program sekolah akan terbengkalai.

2) Meningkatkan pengetahuan guru

Untuk mengikuti perkembangan ilmu pengetahuan yang semakin maju seperti sekarang ini, seorang guru dituntut untuk selalu meningkatkan pengetahuannya baik melalui kursus, membaca buku bacaan, majalah, surat kabar, dan sebagainya, atau melanjutkan studi ke jenjang pendidikan yang lebih tinggi.

3) In service dan Upgrading

Pembinaan dan usaha perbaikan pendidikan tidak mungkin berhasil tanpa disertai dengan pembinaan dan perbaikan mutu pengetahuan serta cara kerja para pelaksana yaitu guru-guru. Diantara usaha pembinaan dan perbaikan mutu pengetahuan guru tersebut dilakukan dengan inservice training dan upgrading. Seperti apa yang diungkapkan oleh Ngalim Purwanto sebagai berikut: Inservice training ialah "segala kegiatan yang diberikan dan diterima 
oleh para petugas pendidikan (kepala sekolah, guru, dsb). yang bertujuan untuk menambah dan mempertinggi mutu pengetahuan, kecakapan dan pengalaman guru-guru dalam menjalankan tugas dan kewajibannya" (Ngalim Purwanto, 1984, p.68).

Program Inservice training dapat mencakup berbagai kegiatan seperti mengadakan aplikasi kursus, ceramah-ceramah, workshop, seminar-seminar, kunjungan ke sekolah-sekolah di luar daerah dan persiapan-persiapan khusus untuk tugas-tugas baru.

Inservice training ini sangat penting bagi guru, karena jika guru itu hanya mengandalkan dari pendidikan formal yang diperoleh di sekolah keguruan dalam mempersiapkan tenaga pendidikan, maka belum merupakan persiapan yang cukup lengkap dan memadai, juga adanya kurikulum sekolah yang mengalami perubahan yang disesuaikan dengan perkembangan ilmu pengetahuan, masyarakat dan kebudayaan. Di samping itu, adanya suatu kenyataan, bahwa karena adanya suatu kebutuhan yang sangat mendesak. Dengan demikian untuk meningkatkan kualitas guru sebagai tenaga pengajar dan tenaga pendidik inservice sangat diperlukan.

Sedangkan up grading (penataran) sebenarnya tidak berbeda jauh dengan inservice training. Upgrading merupakan suatu usaha atau kegiatan yang bertujuan untuk meningkatkan taraf ilmu pengetahuan dan kecakapan para pegawai, guru atau petugas pendidikan lainnya, sehingga dengan demikian keahlian bertambah dan mendalam.

4) Rapat Guru

Rapat guru adalah suatu cara dalam rangka meningkatkan kualitas guru di dalam mengemban tugas dan tanggungjawab sebagai pendidik. Salah satu bentuk rapat guru yang dilaksanakan oleh kepala sekolah ialah konferensi atau musyawarah yang bertujuan untuk membimbing guru-guru agar lebih efektif dalam perbaikan pengajaran di sekolah. Hal ini sesuai dengan ajaran Islam yang disebutkan dalam Al-Qur'an Surat Asy-Syuro ayat 38:

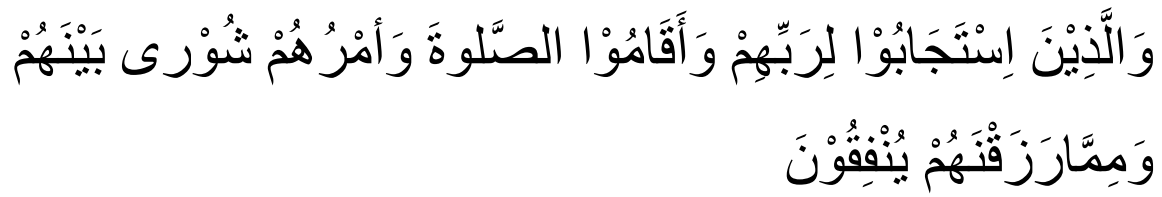

Artinya: (Bagi) orang-orang yang menerima (mematuhi) seruan Tuhanya dan mendirikan sholat, sedang urusan mereka (diputuskan) dengan musyawarah 
antar mereka dan mereka menafkahkan sebagian dari rizki yang kami berikan kepada mereka (Al-Qur'an dan Terjemah, 1989, p.789).

Dari ayat di atas menunjukan bahwa Islam memerintahkan agar dalam menyelesaikan suatu masalah hendaknya dengan musyawarah.

b. Siswa

Dalam meningkatkan mutu pendidikan siswa juga harus mendapatkan perhatian, peningkatan mutu atau kualitas siswa ini dapat dilakukan dengan cara antara lain:

1) Mengaktifkan Siswa

Mengaktifkan siswa ini dilakukan dengan cara misalnya dengan mengabsen siswa setiap kali akan memulai dan akhir pelajaran berlangsung untuk menghindari hal-hal yang tidak diinginkan, seperti siswa meninggalkan sekolah (bolos) sebelum jam pelajaran selesai dan lain-lain.

2) Memberikan Bimbingan

Untuk memperoleh hasil yang memuaskan di dalam belajar, siswa membutuhkan bimbingan. Banyak siswa yang tidak mendapatkan nilai yang baik dalam pelajaranya (di sekolah) karena tidak mengetahui cara-cara belajar yang efektif dan efisien.

Maka dalam mengusahakan agar siswa mempunyai ketrampilan belajar yang baik perlu kiranya seorang guru memberi bimbingan yang berupa petunjuk tentang cara belajar yang baik. Kemudian untuk memberi kebiasaan belajar yang baik bimbingan itu hendaknya diberikan sewaktu-waktu anak mempelajari pelajaran yang disajikan.

3. Faktor Pendukung dan Penghambat Mutu Pendidikan Agama Islam

Dalam upaya meningkatkan mutu pendidikan di suatu lembaga pendidikan. Maka pasti ada problem-problem yang dihadapi, sehingga dapat menghambat upaya peningkatan mutu pendidikan. Adapun problem-problem yang biasanya dihadapi dalam meningkatkan mutu pendidikan adalah: a. Sumber Daya Manusia; b. Peserta Didik; c. Kepala Sekolah; d. Partisipasi Masyarakat; e. Sarana Prasarana (Made Pidarta, 1988, p.198).

\section{Metode Penelitian}

Penulis akan memilih lokasi penelitian pada Madarasah Aliyah Muhammadiyah 02 Paciran Lamongan, tepatnya di jalan pondok paciran Lamongan. Adapun subyek 
penelitiannya adalah kepala Madrasah, Wakil Kepala kurikulum, guru Madarasah Aliyah Muhammadiyah 02 Paciran, dan siswa. Penelitian ini menggunakan pendekatan berparadigma Deskriptif-Kualitatif. Penelitian ini bertujuan untuk menggambarkan realitas empiris sesuai fenomena secara rinci dan tuntas, serta untuk mengungkapkan gejala secara holistis kontekstual melalui pengumpulan data dari latar alami dengan memanfaatkan diri peneliti sebagai instrumen kunci. Dalam penelitian ini penulis menggunakan tiga macam teknik pengumpulan data yaitu metode observasi atau pengamatan, metode wawancara, metode dokumentasi.

\section{Hasil dan Pembahasan}

\section{Peran Kepala Sekolah dalam Meningkatkan Mutu Pendidikan Agama Islam di Madrasah Aliyah Muhammadiyah 02 Paciran}

Berdasarkan hasil wawancara dengan kepala sekolah mempunyai peran untuk memberikan bimbingan kepada guru khususnya guru bidang studi pendidikan agama Islam dan karyawan secara intensif dalam bidang pengembangan dan perencanaan, pelaksanaan dan evaluasi kurikulum. Peran kepala sekolah sebagai supervisor, manajer dan administrator dijalankannya dengan baik. Adapun peran tersebut adalah:

1. Mengontrol dan membimbing guru-guru khususnya guru bidang studi pendidikan agama Islam agar mereka dapat memahami lebih jelas tentang persoalan dan kebutuhan murid, serta usaha-usaha apa yang dapat ditempuh, untuk mengatasi dan memenuhinya.

2. Memberikan penilaian terhadap prestasi kerja sekolah berdasarkan standar-standar sejauh mana tujuan-tujuan sekolah itu telah dapat dicapai.

3. Memberikan pimpinan yang efektif dan demokratis bagi pertumbuhan jabatan guruguru dan staf sekolah lainya demi tercapainya tujuan pendidikan nasional.

4. Memupuk dan mengembangkan hubungan yang harmonis dan kooperatif antara anggota-anggota staf sekolah, dan mengintegrasikan sekolah dengan masyarakat dengan lingkunganya. 
5. Mengikut sertakan orang tua murid (wakil-wakil mereka) dan masyarakat (wakilwakil mereka) dalam usaha penetapan program umum sekolah dan perencanaan, pelaksanaan, serta perbaikan kurikulum bagi sekolah tersebut. Mengajak masyarakat disekitar untuk ikut dalam kegiatan-kegiatan keagamaan serta sosial, seperti memperingati Isro’ Mi’roj dan penggalangan dana sosial.

\section{Usaha Kepala Sekolah Dalam Meningkatkan Mutu Pendidikan Agama Islam di Madrasah Aliyah Muhammadiyah 02 Paciran}

Adapun usaha yang dilakukan kepala sekolah dalam meningkatkan mutu pendidikan agama Islam, berdasarkan wawancara dengan kepala sekolah dapat disimpulkan bahwa pada setiap pelaksanaan pendidikan di suatu lembaga menginginkan lembaga yang dikelolanya akan berhasil dalam mencapai tujuan yang dicita-citakan maka harus ada usaha dari kepala sekolah secara optimal untuk meningkatkan mutu pendidikan khususnya pendidikan agama Islam. Adapun langkah-langkah yang dilakukaan kepala sekolah untuk meningkatkan mutu pendidikan agama Islam adalah sebagai berikut :

1. Berkaitan proses belajar mengajar yang dilaksanakan oleh sekolah, dalam menghadapi masalah ini kepala sekolah membentuk koordinasi guru dibidang studinya dalam rangka agar proses belajar mengajar dapat berjalan dengan lancer melalui rapat dan musyawarah. Kepala sekolah juga menambah jam pelajaran bagi siswa yang lamban dalam menerima materi pendidikan agama Islam terutama dalam membaca Al-Qur'an.

2. Kepala sekolah juga berusaha menambah fasilitas belajar yang diperlukan siswa. Dalam hal ini fasilitas di sana tersebut masih minim sekali misalnya buku bacaan bernuansa religi, peralatan mengajar, serta menambah alat-alat administrasi untuk karyawan.

3. Kepala sekola berusaha mempertinggi mutu dan pengetahuan bagi guru dengan mengadakan diskusi, rapat, musyawarah dan sebagainya. 
4. Mengadakan kerjasama yang baik diantara guru-guru, masyarakat, orang tua dan instansi lainnya.

5. Melengkapi buku perpustakaan terutama buku tentang keagamaan karena penting bagi perkembangan mutu Pendidikan agama Islam.

6. Kepala sekolah memberi motivasi kepada guru dan karyawan dengan mengadakan dialog tentang kegiatan guru selama mengajar baik mengenai materi atau yang lainnya.

7. Kepala sekolah memperhatikan perkembangan kegiatan siswa pada kegiatan proses belajar mengajar dalam hal ini kepala sekolah melihat langsung yang dipakai oleh guru, buku laporan kegiatan siswa, buku absensi dan buku absensi siswa dan menambah materi di luar jam pelajaran.

Faktor Pendukung dan Penghambat Mutu Pendidikan Agama Islam di Madrasah Aliyah Muhammadiyah 02 Paciran

\section{Faktor Pendukung}

a. Guru yang mempunyai kedisiplinan dan keteladanan

Guru adalah sangat penting bagi perkembangan anak didik, guru selaku pendidik mempunyai semangat yang tinggi untuk meningkatkan keaktifan siswa dalam proses belajar mengajar siswa dan guru harus mempunyai buku pegangan sesuai dengan materi yang disampaikan. Serta guru harus memberi contoh yang baik kepada siswanya agar mutu pendidikan khususnya pendidikan agama Islam bisa terwujudkan.

b. Siswa yang mempunyai prestasi dan bakat

Siswa ada di Madrasah Aliyah Muhammadiyah 02 Paciran mempunyai motivasi dalam proses belajar baik di sekolah maupun di luar jam sekolah dan keadaan siswa yang ada di sini rata-rata mempunyai semangat yang sama. 
c. Sumber daya manusia di lingkungan sekolah

Masyarakat yang tinggal di sana sangat berperan sekali dalam perkembangan mutu pendidikan yang ada di sana meskipun keadaan ekonomi masyarakat yang rata-rata dalam tingkatan ekonomi menengah.

d. Adanya fasilitas masjid.

Dengan adanya masjid kegiatan belajar mengajar pandidikan agama Islam lebih mudah dan mengena karena bisa dimanfaatkan untuk kegiatan-kegiatan keagamaan di luar jam pelajaran.

\section{Faktor Penghambat}

Kendala yang ada dalam perkembangan sekolah tersebut diantaranya adalah:

a. Fasilitas belajar

Fasilitas belajar di Madrasah Aliyah Muhammadiyah 02 Paciran masih belum maksimal terutama pada jumlah ruangan dan media pembelajaran.

b. Perpustakaan

Keadaan perpustakaan di Madrasah Aliyah Muhammadiyah 02 Paciran sebenarnya sudah berkembang dalam arti sudah diminati setiap siswa akan tetapi melihat terbatasnya buku yang dimiliki sekolah tersebut masih terbatas. Hal itu juga merupakan faktor penghambat proses belajar siswa akan tetapi kepala sekolah akan berusaha untuk menambah buku bacaan lebih-lebih buku pengetahuan umum.

c. Faktor dana 
Dana menjadi faktor utama dalam perkembangan mutu pendidikan, di mana jika mempunyai dana yang lebih akan dapat membangun dan melengkapi kebutuhan yang diperlukan bagi sekolah.

\section{Kesimpulan}

Hasil penelitian diambil kesimpulan berikut ini:

1. Peran Kepala Sekolah dalam meningkatkan mutu pendidikan agama Islam di Madrasah Aliyah Muhammadiyah 02 Paciran.

a. Mengontrol dan membimbing guru-guru khususnya guru bidang studi pendidikan agama Islam agar mereka dapat memahami lebih jelas tentang persoalan dan kebutuhan murid, serta usaha-usaha apa yang dapat ditempuh, untuk mengatasi dan memenuhinya.

b. Memberikan pimpinan yang efektif dan demokratis bagi pertumbuhan jabatan guru-guru dan staf sekolah lainnya demi meningkatkan mutu pendidikan agama Islam.

2. Usaha Kepala Sekolah dalam meningkatkan mutu pendidikan agama Islam di Madrasah Aliyah Muhammadiyah 02 Paciran.

a. Membentuk koordinasi guru di bidang studinya dalam rangka agar proses belajar mengajar dapat berjalan dengan lancar melalui rapat dan musyawarah. Dan juga menambah jam pelajaran bagi siswa yang lamban dalam menerima materi pendidikan agama Islam khususnya dalam membaca Al-Qur'an.

b. Berusaha melengkapi alat-alat prasarana dan perlengkapan sekolah termasuk media instruksional yang diperlukan bagi kelancaran dan keberhasilan proses belajar mengajar.

3. Faktor Pendukung dan Penghambat Mutu Pendidikan Agama Islam di Madrasah Aliyah Muhammadiyah 02 Paciran. 

a. Faktor Pendukung
b. Faktor Penghambat

\section{Daftar Rujukan}

E. Mulyasa, 2004, Kurikulum Berbasis Kompetensi Konsep, Karakteristik Dan Implikasi Bandung: PT.Remaja Rosdakarya

Hadari Nawawi, 1985, Administrasi Pendidikan, Jakarta: Gunung Agung

Hendiyat Sutopo dan Wasty Suemanto, 1982, Kepemimpinan Dalam Pendidikan, Surabaya: PT. Usaha Nasional

M. Daryanto, 2001, Administrasi Pendidikan, Jakarta: PT. Rineka Cipta

Muhammad Ali, 2000, Guru Dalam Proses Belajar Mengajar, Bandung: Sinar Baru

Ngalim Purwanto, 1990, Administrasi dan Supervisi Pendidikan, Bandung: PT. Remaja Rosda Karya,

S. Nasution, 1991, Kurikulum dan Pengajaran, Jakarta: Bumi Aksara

Subhan Adi Santoso, 2020. Media Pembelajaran Pendidikan Agama Islam Era Industri 4.0. Yogyakarta: Deepublish

Subhan Adi Santoso, M. Chotibuddin, 2020. Pembelajaran Blended Learning Masa Pandemi. Pasuruan: Qiara Media

Subhan Adi Santoso, Ali Mustofa, 2019. Ilmu Pendidikan Islam Era Industri 4.0. Malang: Media Sutra Tiga

Subhan Adi Santoso, Maulidyah Amalina Rizqi 2020. Kinerja Pengawas Sekolah, Kepala Sekolah, dan Guru pada Pendidikan. Yogyakarta: Deepublish

Subhan Adi Santoso, 2017. Korelasi Motivasi Belajar Terhadap Prestasi Belajar Siswa Kelas X Mata Pelajaran PAI Di SMKN 13 Malang. Jurnal Tamaddun: Vol. 18 No. 1. 2017 
Subhan Adi Santoso, 2017. Pengaruh Kompetensi Pedagogik Guru Terhadap Prestasi Belajar Siswa Kelas XI Mata Pelajaran PAI Di SMKN 13 Malang. Jurnal Tamaddun: Vol. 18 No. 2. 2017

Subhan Adi Santoso, 2017. Implementasi Kurikulum 2013 Dalam Kegiatan Pembelajaran Pendidikan Agama Islam Di Sekolah Menengah Kejuruan Negeri 13 Malang. Jurnal Annaba: Vol. 3 No. 1. 2017

Subhan Adi Santoso, 2017. Problematika Pembelajaran Agama Islam Di Sekolah Menengah Kejuruan Negeri 13 Malang. Jurnal Annaba: Vol. 2 No. 1.2016

Wijono, 1989, Administrasi Dan Supervisi Pendidikan, Jakarta: Departeman Pendidikan Dan Kebudayaan

Zahara Idris dan Lisma Jamal, 1992,Pengantar Pendidikan, Jakarta: Gramedia Widiasarana Indonesia 